\title{
"SWEET BUT DANGEROUS": NECTARIES IN CARNIVOROUS PLANTS
}

\author{
Bartosz Jan Plachno \\ Department of Plant Cytology and Embryology, Jagiellonian University, Grodzka 52, 31- 044 Cracow, Poland \\ e-mail: bartek78pl@poczta.onet.pl
}

Received: 24.09 .2007

\begin{abstract}
S u m m a r y
In carnivorous plants, two types of nectaries occur: extra-floral nectaries, generally associated with prey luring, and floral ones associated with pollination. Nectar produced by extra-floral nectaries not only attracts prey but may also be involved in trapping prey and plays a role in myrmecophily. The diversity of nectary structure in carnivorous plants reflects complicated evolutionary routes in this unique ecological group.
\end{abstract}

Key words: nectaries, nectar, carnivorous plants, carnivorous syndrome, osmophores, pollination

\section{INTRODUCTION}

Carnivorous plants are common both in the education and science. They are useful material in children education; see several books for kids e.g.: B a t te n 2000 "Hungry plants", but also for academic students. The scientific interest in carnivorous plants is still increasing (Porembski and Barthlott, 2006). Carnivorous plants are important as a model system in ecological and biological cell research (e.g. E 11 is o n et al. 2003; Adlassnig et al. 2005; Płachno et al. 2007). They are also used as ornamental plants. Several international retailers sell carnivorous plants which are reproduced using in vitro cultures. Many carnivorous plants are very easily grown as home plants; others are suitable and attractive for outdoor cultivation. Especially Sarracenia are favorite plants for garden bogs and fens in temperate countries. Pitchers of Sarracenia are used by floriculturists as cut "flowers". For this purpose, species and hybrids which produce tall and upright pitchers are preferred. It is worth mentioning that only in the USA several millions of pitchers of S. leucophylla are sold every year (R o m a n o w s k i, 2002).

In carnivorous plants two types of nectaries occur: extra-floral nectaries which are generally associated with prey attraction and floral ones associated with pollination. The anatomy of extra-floral nectaries of carnivorous plants was summarized by L 1 o y d (1942), later by J u n i p e r et al. (1989). Recently, new and important pieces of information on both extra- and floral nectaries in carnivorous plants were added by Vog e 1 (1998). In the last years, interactions between nectaries and animals were deeply studied in Nepenthes. In some species of this genus, extra-floral nectaries play a role in myrmecophily (M e rbach et al. 1999; Merbach et al. 2000; M e rbach et al. 2007). Nectar produced by the extra-floral nectaries not only attracts prey but is also involved in trapping prey alone. The presence of a nectar film on the surface of the Nepenthes peristome disrupts an attachment for adhesive insect pads ( $\mathrm{B}$ o h $\mathrm{n}$ and F e derle, 2004). Some of nectaries in carnivorous plants may have similar role as osmophores e.g. in Heliamphora, nectary cells have features of cells producing monoterpenes ( $\mathrm{P} \nmid \mathrm{a}$ c h n o et al. 2007a). Also, progress in cultivation of "difficult", rare and endangered carnivorous plants and in exploration of their unique habitats such as: tepuis, ghats, and tropical forest, improves our knowledge on both prey attraction and pollination in this special ecological group of plants.

The aim of this paper is to shortly summarize recent knowledge on nectaries in selected genera of carnivorous plants.

\section{Survey of the genera \\ Extrafloral nectaries}

Extra-floral nectaries occur in carnivorous plants, forming pitfall traps (Darlingtonia, Heliamphora, Sarracenia, Cephalotus, Nepenthes), and in Dionaea forming snap-trap (J u n i p e r et al. 1989).

\section{Sarracenia}

Nectaries occur in the attractive zone of the pitcher, including the inside of the lid, and are especially abundant on the peristome surface (Figs 1-3). Nectaries form nectar guides on the outer pitcher surface (J uniper et al. 1989; Voge 1, 1998). The nectary 

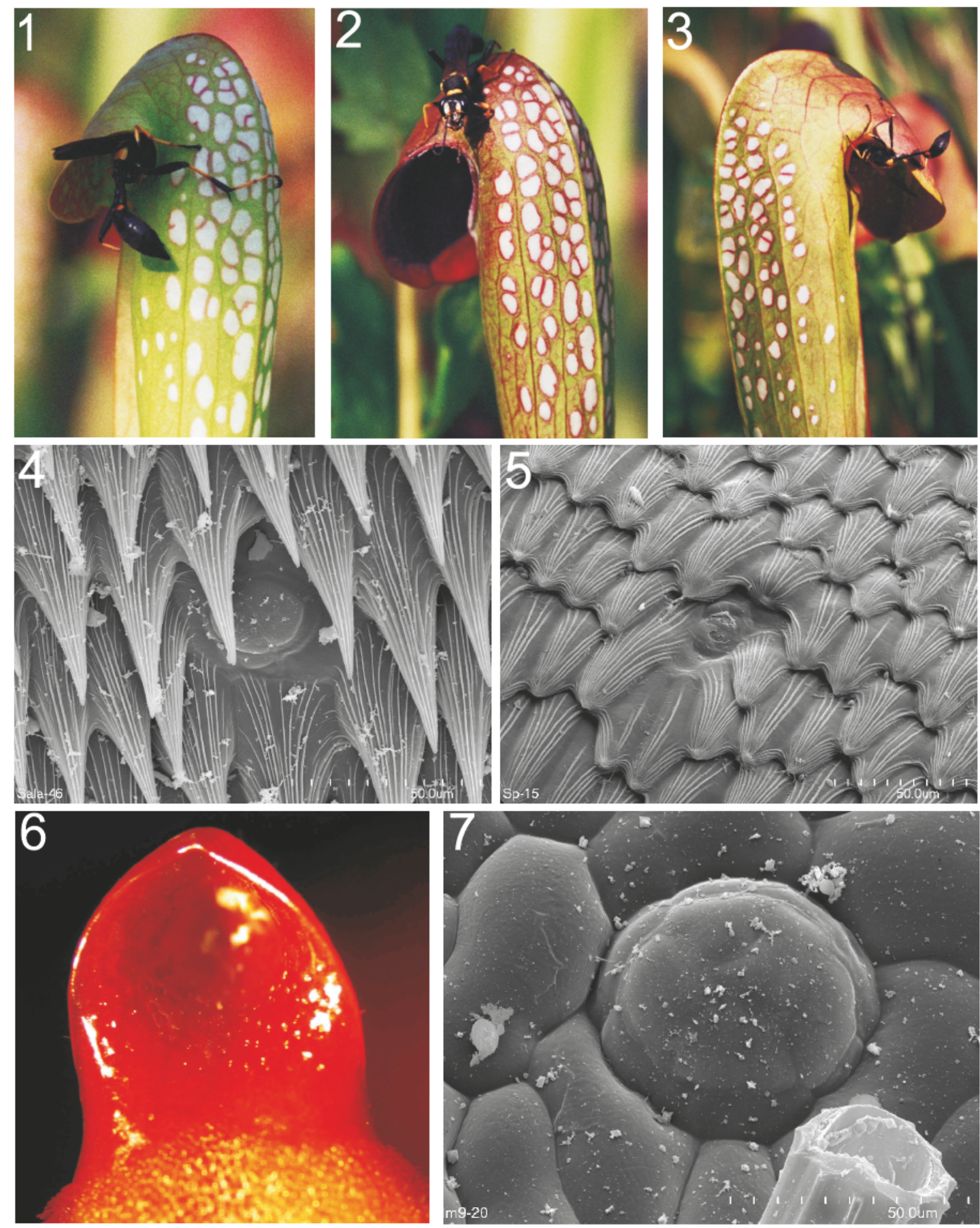

Figs 1-3. Wasps looking for nectar on the pitchers of Sarracenia minor, Meadowview Biological Research Station, Virginia, USA. Fig. 4. Nectary fom the attractive zone of the pitcher of S. alabamensis.

Fig. 5. Nectary fom the attractive zone of the pitcher of S. purpurea.

Fig. 6. The nectar spoon of Heliamphora heterodoxa pitcher, note nectar drop.

Fig. 7. Small nectary fom the attractive zone of the pitcher of Heliamphora minor. 

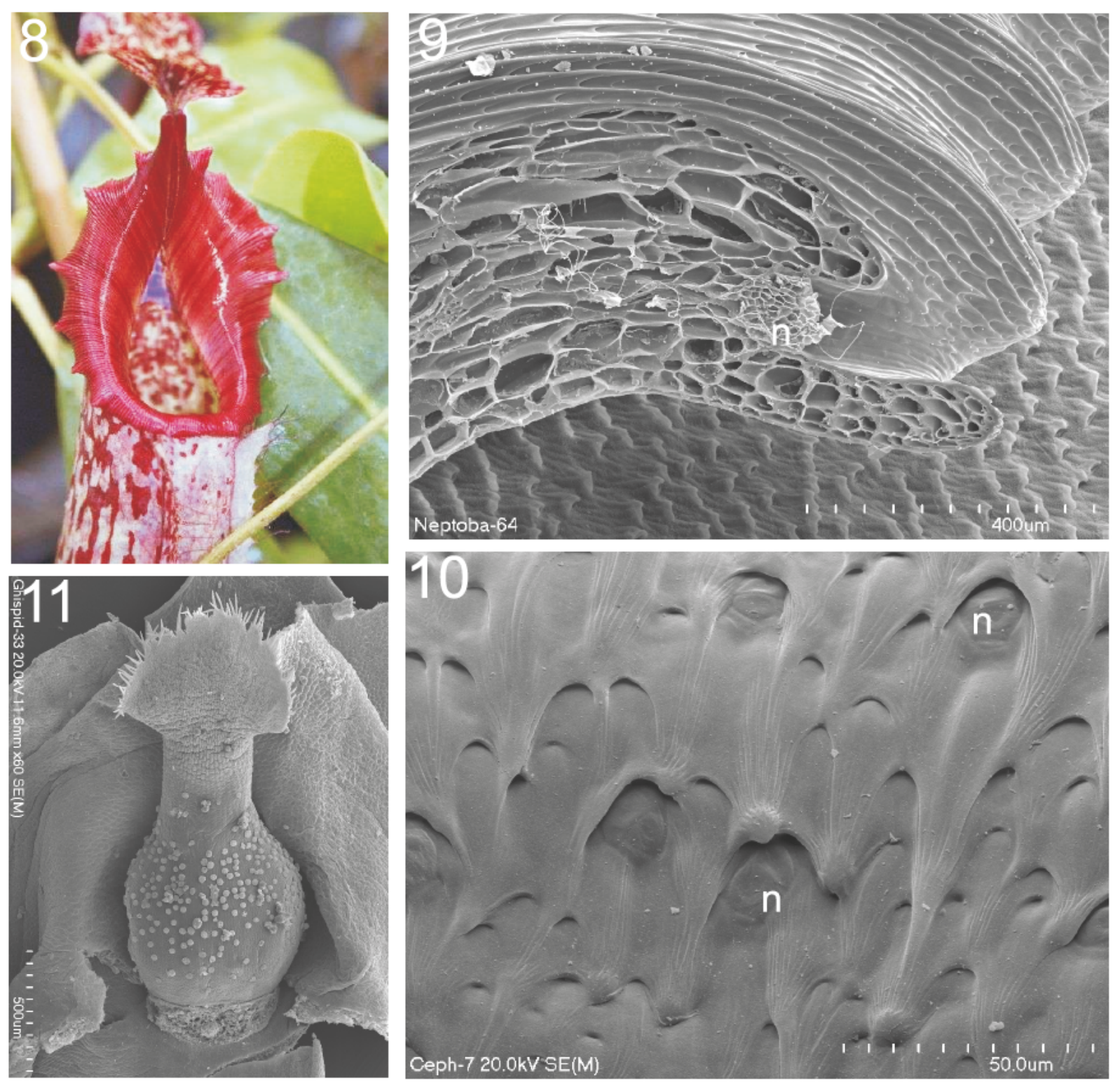

Fig. 8. Pitcher of Nepenthes hybride with magnificent peristome.

Fig. 9. Peristome nectary (n) of Nepenthes tobaica.

Fig. 10. Nectaries (n) from the pitcher of Cephalotus follicularis.

Fig. 11. Style of Utricularia australis with numerous small nectaries.

from the attractive zone of the pitcher has similar architecture across the genus ("Sarracenia-type" Figs 4-5) and consists of 10-12 cells. Its base has a contact with two to five cells with reticulate or spirally thickened cell walls (L 1 o y d , 1942). The density is $30-50$ nectaries per $\mathrm{mm}^{2}$ in the attractive zone of the pitcher (Vo g e 1, 1998).

\section{Darlingtonia}

Darlingtonia californica Torrey, endemic to southern Oregon and northern California, USA, forms tall pitchers with a characteristic fishtail appendage, which directs a potential prey towards the trap entrance, hence the common name of this plant is "cobra lily". Insects are attracted by the sweet fragrance, nectar, and also by appendage coloration (e.g., S chne 11, 2002; $\mathrm{Rice}, 2006)$. The nectar is secreted by the extrafloral nectaries which occur on the fishtail appendage, mouth, and hood of the pitcher. They are small, few-celled, and completely sunken in parenchyma (L l o y d , 1942). Nectar lures many insects, e.g., wasps, however, the trap is very ineffective because only about $2 \%$ of visiting insects are caught (D i x o n et al. 2005). 


\section{Heliamphora}

In Heliamphora there are two kinds of nectaries: giant ones restricted to the nectar spoon (Fig. 6) and small ones (Fig. 7) which occur on the outer and partly on the inner pitcher surface. The latter type of nectaries has a basic structure very similar to the extra-floral nectaries of Sarracenia; "Sarracenia-type" (L 1 o y d, 1942; Vogel, 1998). The giant nectaries are the major source of nectar, their anatomy was perfectly described using light microscopy by L l o y d (1942). However, their ultrastructure has just recently been studied ( $\mathrm{P} \nmid \mathrm{ach} \mathrm{n} \mathrm{o}$ et al. 2007a). It is worth mentioning Heliamphora folliculata, a species which forms a chamber to store nectar (W i s t u b a et al. 2001). However, nectaries of this species have similar architecture as other species in this genus (Pła c h n o et al. 2007a). In some species, nectar production is very large, and nectar trickles from nectar spoon to the interior of the pitcher ( $\mathrm{M} \mathrm{c} \mathrm{P} \mathrm{h} \mathrm{e} \mathrm{r} \mathrm{s} \mathrm{o} \mathrm{n}$, 2007). H. neblinae has mutual interactions with ants which protect traps. It produces nectar collected by ants which, what is more interesting, use the old, dead traps as nests (M c P h e r s o n, 2007). Heliamphora traps produce not only nectar but also several volatile compounds, e.g. enol diacetal monoterpene (sarracenin), erucamide, phenol, cinerone, phenylacetaldehyde and methyl esters for prey attraction ( $\mathrm{J}$ a ffé et al. 1995).

\section{Nepenthes}

Extrafloral nectaries occur in the whole $\mathrm{Ne}$ penthes plant (stem, leaves, and inflorescence), excluding petals where the floral nectaries occur ( $\mathrm{M} \mathrm{a} \mathrm{c} \mathrm{far} \mathrm{-}$ 1 a n e, 1908; M e r b a c h, 2001). There are differences in distribution, quantity, and size of nectaries among species (Merbach et al. 2001). After Merbach (2001), there are the three main types of extrafloral nectaries in this genus: spherical hollow nectaries, disclike nectaries, and peristome nectaries (Figs 8-9). From an anatomical and morphological point of view, disclike nectaries resemble digestive glands from pitchers (P a r k e s, 1980). In some species as in N. maxima, nectaries in the pitcher rim may form a ring of the secretory tissue ( $\mathrm{P}$ a r k e s , 1980). It is to underline that there are especially large nectaries which occur on the pair of sharp thorns under the pitcher lid of $N$. bicalcarata (M e r b a c h , 1999). The nectary anatomy in this genus was described in detail by several authors, e.g., L 1 o y d (1942) and P arke s (1980). However, their ultrastructure was examined only by Va s s i ly e v (1977) who studied peristomal nectaries; later his results were repeated by Juniper at al. (1989), thus they are not mentioned here in my paper. Generally, extrafloral nectaries on the pitcher surface are associated with prey attraction. For example in N. ampularia, a species which uses leaf litter as a source of nitrogen and rarely catches prey (M o $\mathrm{r}$ a et al. 2003), nectaries from the pitcher lid are rare or event absent, moreover nectaries from the peristome are small as compared to other species (C la r k e, 2001). However, some Nepenthes species may produce nectar for a different purpose. Sunbirds feed on nectar from pitcher lids e.g. in $N$. faizaliana (see Fig. 25 in $\mathrm{C} 1 \mathrm{a} \mathrm{r}$ $\mathrm{ke}, 1997)$. N. lowii has upper pitchers with a unique shape which produce a white sugar-rich substance at the tips of the bristles under the lid. This substance, which is different than nectar in other Nepenthes species, allures birds. It was suggested that this species more benefits from trapping of birds and mammalian excrements than from catching insects (C l a r k e, 1997).

In some Nepenthes species, extra-floral nectaries fulfill also an important role in the mutual interactions between the plant host and ants. Ants protect the host against herbivores, e.g., from weevils which destroy pitchers (M e r b a c h et al. 2007). Myrmecophily is documented the best in $N$. bicalcarata, which is the host for Campanotus schmitzi that makes its nest in the pitcher hollow tendrils. These ants "swim" in the pitcher fluid, retrieve a part of prey caught by the plant (C l a r k e and K itching, 1995), and also exploit nectar produced by the host plant (M e r b a c h et al. 1999).

Pitchers of Nepenthes usually do not produce a strongly sweet odour, thus their nectaries are not osmophores, though $N$. rafflesiana has fragrant pitchers with a strong sweet scent (Philips and L a m b , 1996). Commonly, pitchers, which are full of carcasses of prey, emit a special odour which may attract insects like calliphorid and muscid flies (C l a r k e, 2001).

\section{Cephalotus}

Nectaries occur on the outer pitcher surface but mostly on the lid surface and teeth (Fig. 10). The nectary has a very simple architecture, it consists of 6 secretory cells and several endodermal cells with lignified transverse walls (P a r k s , 1980).

\section{Floral nectaries}

Some carnivorous plants lack flower nectaries. For example, Drosera anglica produces the fragrance-lacking, nectarless flowers, which are rarely pollinated by insects. Self-pollination in this species is responsible for the main seeds production (M u r z a and Davis, 2005). Similar observations were done on $D$. rotundifolia and D. linearis ( $\mathrm{M} \mathrm{u} \mathrm{r} \mathrm{z} \mathrm{a} \mathrm{and} \mathrm{D} \mathrm{a} \mathrm{v} \mathrm{is} \mathrm{,} \mathrm{2003).} \mathrm{In} \mathrm{other}$ Drosera species, especially tropical and subtropical, the pollination mechanism may be different. For example, flowers of some Drosera species are visited by birds. Future research on pollination mechanism in this genus is needed ( $\mathrm{M} \mathrm{u}$ r z a and D a v i s , 2005). Within Sarraceniaceae family, the genus Heliamphora produces nectarless, pollen-flowers, and is pollinated by bumblebees (R e n n e r, 1989; Vog e 1, 1998). 


\section{Utricularia}

Some Utricularia species produce cleistogamous flowers which do not need insects, but probably all Utricularia species produce chasmogamous flowers which are attractive for animals. Species vary both in flower colors and size (T a y l o r, 1989). Many types of hairs occur on the flower surface (F a r o o q and $\mathrm{S} \mathrm{i} \mathrm{d} \mathrm{-}$ d i qu i , 1966) and some of them are secretory. Several Utricularia species classed with different sections have the same type of nectaries. The nectary has a very simple architecture and consists of a basal cell, a middle cell with a Casparian-like lateral cell wall, and a multicellular head which produces nectar (P ł a c h n o in preparation). This kind of glandular hairs occurs commonly in the spur but may also occur in different parts of flower, e.g., style (Fig. 11) (F a r o o q and S i d d i qu i, 1966; Taylor, 1989). Nectar is produced inside the spur (e.g., H o b b h a h n et al. 2006) but in some species, e.g. $U$. dichotoma, droplets of nectar were observed on the external spur surface ( $\mathrm{P} \nmid \mathrm{ach}$ n o unpub.). However, Jérémie (1989) suggested that in autogamous Utricularia alpina nectar was not produced. In some Utricularia, e.g., in U. purpurascens, the same population of both flowers with and without nectar occur (A $\mathrm{n}$ a n d et al. 2007). For long time, only sparse information on pollination biology of this genus was available, however, a detailed study on pollination of some terrestrial Utricularia species in the Indian Western Ghats has recently been published (Hob b hahn et al. 2006). These authors found that more than 50 species of various insects (bees, butterflies, moths, hawk month, dipterans) had visited flowers. Though the nectar of this terrestrial Utricularia species is rich in sugar, it is produced in extremely small volumes ( $\mathrm{H} \mathrm{o} \mathrm{b} \mathrm{b} \mathrm{h} \mathrm{a} \mathrm{h} \mathrm{n} \mathrm{et} \mathrm{al.} \mathrm{2006).} \mathrm{Some} \mathrm{species}$ (U. campbelliana, U. quelchii) are visited and probably pollinated by hummingbirds (T a y 1 o r , 1989).

\section{Sarracenia and Darlingtonia}

Sarracenia flowers produce nectar at the glabrous ovary. Nectar in the flowers was reported in $S$. flava, $S$. minor and $S$. purpurea, but floral nectaries were studied in detail only in $S$. purpurea by Vog e 1 (1998). They are a larger version (60-100 cells) of nectaries from the pitcher attractive zone and occur in the basis of ovary tubercles. There are about 50 nectaries per $\mathrm{mm}^{2}$. The floral nectar has a similar composition as the nectar produced by extra-floral nectaries (Vo g e 1, 1998).

Sarracenia flowers emit a fragrance which, in the same way as nectar, attracts pollinators, but there are differences between species or groups of species: e.g., $S$. oreophila, S. flava - flowers have feline fragrance, S. minor - watermelon fragrance, S. rubra - sweet, $S$. jonesii and $S$. alabamensis - strawberry fragrance (S c h n e 11, 2002; R i c e, 2006). The primary pollinator of $S$. purpurea are queen bumblebees, but pollination of other species of Sarracenia still needs further study (S c hn e 11, 2002).

In contrast to Sarracenia, the occurrence of the floral nectaries in Darlingtonia is under debate. For instance, according to D e B uhr (1973, after Vo g e l, 1998) nectar is totally absent. However, Schnell (2002) pg. 234 wrote shortly that in Darlingtonia flower "nectar from the basal glands" occurred.

\section{Nepenthes}

Nepenthes is a dioecious genus. Both female and male flowers possess nectaries, however, the females produce a more concentrated nectar (F r a z i e r, 2001). Floral nectaries have similar architecture as disc nectaries from vegetative parts.

Several insects visit Nepenthes flowers, but most effective pollinators are moths, flies, wasps, and butterflies (Fra zi e r, 2001).

\section{Cephalotus}

In contrast to the showy pitchers, Cephalotus produces inconspicuous, small entomophilous flowers. The flower produces honey-like scent and has a nectar disk with around 135 emergences (pillars). The disc has features of a mesenchymatic nectary. The pillars are filled with glandular tissue. On the top of the each pillar, there is an immobile, open stoma through which nectar is secreted. The nectar is rich in glucose and fructose (Vog e 1, 1998).

\section{CONCLUSION}

The diversity of nectary structure in carnivorous plants reflects complicated evolutionary routes of this ecological group.

\section{Acknowledgements}

Major part of this paper was written during my stay at Indiana University Southeast (USA). The author is greateful to Douglas Darnowski (Indiana University Southeast) and Philip M. Sheridan (Meadowview Biological Research Station, Virginia, USA) for their hospitality. Sincere thanks are due to Lubomir Adamec and Douglas Darnowski for reading the manuscript and correction of the language.

\section{REFERENCES}

Adlassnig W., Peroutka M., Lang I., Lichtscheidl I. K., 2005. Glands of carnivorous plants as a model system in cell biological research. Acta Bot. Gallica, 152: 111-124.

Anand Ch., Umranikar Ch., Shintre P., Damle A., Kale J., Joshi J., Watv M., 2007. Presence of two types of flowers with respect to nectar sugar in two gregariously flowering species. J. Bioscience. 32: 769-774. 
Batten M., 2000. Hungry Plants. A Golden Book, New York.

Bohn F. F., Fed erle W., 2004. Insect aquaplaning: Nepenthes pitcher plants capture prey with the peristome, a fully wettable water-lubricated anisotropic surface. PNAS, 101: 14138-14143.

Clarke C. H., 1997. Nepenthes of Borneo. Natural History Publications (Borneo) Kota Kinabalu.

Clarke C. H., 2001. Nepenthes of Sumatra and Peninsular Malaysia. Natural History Publications (Borneo) Kota Kinabalu.

Clarke, C. H., Kitching R. L., 1995. Swimming Ants and Pitcher Plants: a Unique Ant-Plant Interaction from Borneo. J. Tropic. Ecol. 11: 589-602.

Dixon P. M., Ellis on A. M., Gotelli N. J., 2005. Improving the precision of estimates of the frequency of rare events. Ecology, 86: 1114-1123.

Ellison A. M., Gotelli N. J., Brewer J. S., CochranStafira D. L., Kneitel J., Miller T. E., Worley A. C., Z a m or a R., 2003. The evolutionary ecology of carnivorous plants. Adv. Ecolog. Res. 33: 1-74.

Farooq M., Siddiqui S. A., 1966. Trichomes on the floral parts of Utricularia. Beitr. Biol. Pflanzen, 42: 353-361.

Frazier Ch. 2001., Pollination and reproductive strategies of Nepenthes. [In] Nepenthes of Sumatra and Peninsular Malaysia. C. H. Clarke (ed.), Natural History Publications (Borneo) Kota Kinabalu, pp. 68-73.

Hobbhahn N., Küchmeister H., Porembski S., 2006. Pollination biology of mass flowering terrestrial Utricularia species (Lentibulariaceae) in the Indian Western Ghats. Plant Biology, 8: 791-804.

Jaffé K., Blum M. S., Fales H. M., Mas on R. T., Cabrera A., 1995. On insect attractants from pitcher plants of the genus Heliamphora (Sarraceniaceae) J. Chem. Ecol. 21: 379-384.

Jérémie J., 1989. Autogamie dans le genre Utricularia (Lentibulariaceae). Bulletin du Museum National d'Historie Naturelle, section B, Adansonia, 11: 17-28.

Juniper B. E., Robins R. J., Joel J. M., 1989. The Carnivorous Plants. Academic Press, London.

Lloyd F. E., 1942. The Carnivorous Plants. Chronica Botanica Company, Waltham, Mass. USA.

Macfarlane, J. M., 1908. Nepenthaceae. [In] Das Pflanzenreich IV, III (Heft 36). A. Engler (ed.).

MacPherson S., 2007. Pitcher plants of the Americas. The McDonald \& Woodward Publishing Company, Blacksburg, Virginia, and Granville, Ohio.

Merbach M. A., 2001. Nectaries in Nepenthes. [In] Nepenthes of Sumatra and Peninsular Malaysia. C.H. Clarke (ed.), Natural History Publications (Borneo) Kota Kinabalu, pp. 73-75.

Merbach M. A., Zizka G., Fiala B., Merbach D., Maschwitz U., B ooth W. E., 1999. Giant nectaries in the peristome thorns of the pitcher plant Nepenthes bicalcarata Hook F. (Nepenthaceae): Anatomy and functional aspects. Ecotropica, 5: 45-50.

Merbach M. A., Zizka G., Fiala B., Maschwitz U., and B o oth W. E., 2000. Carnivory and myrmecophytism-a contradiction? Studies on Nepenthes bicalcarata Hook $\mathrm{f}$. and its ants. Tagungsband gtö 2000 13. Jahrestagung der Deutschen Gesellschaft für Tropenökologie 1-3. March 2000 in Würzburg Lehrstuhl für Tierökologie und Tropenbiologie Universität Würzburg. p. 106.

Merbach M. A., Zizka G., Fiala B., Maschwitz U., and B ooth W., 2001. Pattern of nectar secretion in five Nepenthes species from Brunei Darussalam, Northwest Borneo, and implications for ant-plant relationships. Flora, 196: 153-160.

Merbach M. A, Zizka G., Fiala B. Merbach D., Booth W. E., Mas chwitz U., 2007. Why a carnivorous plant cooperates with an ant: selective defense against pitcher-destroying weevils in the myrmecophytic pitcher plant Nepenthes bicalcarata Hook.f. Ecotropica, 13: 45-56.

Moran A. J., Clarke Ch. M., Hawkin s B. J., 2003. From carnivore to detritivore? Isotopic evidence for leaf litter utilization by the tropical pitcher plant Nepenthes ampullaria. Int. J. Plant Sci. 164: 635-639.

Murza G. L., Davis A. R., 2003. Comparative flower structure of three species of sundew (Drosera anglica, Drosera linearis, and Drosera rotundifolia) in relation to breeding system. Can. J. Bot. 81: 1129-1142.

Murza G. L., Davis A. R., 2005. Flowering phenology and reproductive biology of Drosera anglica (Droseraceae). Bot. J. Linn. Soc. 147: 417-426.

Parkes D. M., 1980. Adaptive mechanizm of surface and glands in some carnivorous plants. MSc Thesis, Monash University, Clayton, Victoria, Australia.

Phillipp s A., La mb A., 1996. Pitcher-Plants of Borneo. Natural History Publications (Borneo), Kota Kinabalu.

Płachno B. J., Kozieradzka-Kiszkurno M., Świątek P., 2007. Functional Utrastructure of Genlisea (Lentibulariaceae) Digestive Hairs. Ann. Bot. 100: 195-203.

Płachno B. J., Świątek. P., Wistuba A., 2007a. The giant extra-floral nectaries of carnivorous Heliamphora folliculata: architecture and ultrastructural. Acta Biol. Cracov. Bot. 49(2): 91-104.

Porembski S., Barthlott W., 2006. Advances in carnivorous plant research. Plant Biol. 8: 737-739.

Renner S., 1989. Floral biological observations on Heliamphora tatei (Sarraceniaceae) and other plants from Cerro de la Neblina in Venezuela. Plant Syst. Evol. 163: 21-29.

Rice B. A., 2006. Growing Carnivorous Plants. Timber Press, Portland.

Romanowski N., 2002. Gardening with carnivores. Sarracenia pitcher plants in cultivation \& in the wild. University Press of Florida, Gainesville.

Schnell D. E., 2002. Carnivorous plants of the United States and Canada. Timber Press, Portland, Oregon.

Taylor P., 1989. The Genus Utricularia - A taxonomic monograph. Kew Bulletin, 14: 1-735.

Wistuba A., Harbarth P., Carow T., 2001. Heliamphora folliculata, a new species of Heliamphora (Sarraceniaceae) from the 'Los Testigos' table mountains in the South of Venezuela. Carnivor. Plant Newslet. 30: 120-125. 
Vassilyev A. E., 1977. Functional morphology of plant secretory cells. (In Russian), Nauka Press, Leningrad.

Vogel S., 1998. Remarkable nectaries: structure, ecology, organopyletic perspectives II. Nectarioles. Flora, 193: 1-29.

„Słodkie ale niebezpieczne": nektarniki u roślin mięsożernych

\section{Streszczenie}

U roślin mięsożernych występują dwa typy nektarników: kwiatowe oraz pozakwiatowe. Pierwsze odpowiadają za wabienie zapylaczy, natomiast drugie za przywabienie zdobyczy. Nektar wytwarzany przez nektarniki pozakwiatowe jest produkowany przede wszystkim w celu zwabienia zdobyczy, ale może także uczestniczyć w mutualistycznych interakcjach pomiędzy rośliną mięsożerną a mrówkami. Zróżnicowana architektura nektarników u roślin mięsożernych jest skorelowana ze skomplikowaną ewolucją tej specyficznej grupy ekologicznej roślin. 
